\title{
DETERMINANTS OF SUKUK (ISLAMIC BONDS) YIELDS
}

\author{
Dr. Hebah Shafeq Shalhoob \\ Princess Nourah Bint Abdlrahman University, Faculty of \\ Business \& Administration, Accounting Department
}

\begin{abstract}
Sukuk are a significant mode of financing in the Islamic financial system. Since their launch in the 1980s, Sukuk have gained recognition and popularity as a substitute for conventional bonds. Sukuk represent a proportional undivided ownership right in tangible assets, or a pool of predominantly tangible assets. The aim of this study to identify a number of factors that can be used to demonstrate the relationships between bond yields by employing OLS regression analysis. The results from the regression analysis suggested that maturity, size, Ijara, sovereign Sukuk, and credit rating have significant results on Sukuk yield. The findings of this study could be helpful for investors to get better risk-adjusted returns in bonds markets. For policy makers, it highlights the importance of further developments in Sukuk markets.
\end{abstract}

Key Words: Islamic finance, Islamic bonds, Sukuk.

\section{INTRODUCTION}

Investors should be concerned about how well their investments are performing, thus knowing how to measure such performance is vital in finance. It is therefore important to understanding the determinants that influence bond 45T59Tyields45T59T.

Yield is an investment earnings without considering capital gains. It is used to measure the performance of bond income. 
Yield to maturity is the rate of return that is earned by an investor from coupon and principal payment at maturity by the bond issuer. The yields on different maturities by government bonds give the term structure of the interest rates of that country.

The term structure of interest rates provides an important benchmark for that financial system. The yield to maturity is not constant over time. The yield to maturity of a bond changes whenever its price changes in response to any news about its issuer or due to any change in the rating of that issuer. Sukuk have attracted a huge number of investors around the world, therefore encouraging recent studies about the determinants of their yield.

This study aims to investigate the determinants of Sukuk yields in the Sukuk market. This is due to the fact that Sukuk structures are more complicated than conventional bonds. In other words, it aims to identify a number of factors that can be used to demonstrate the relationships between bond yields. The main variables that affect bond yields are maturity, risk, Sukuk type, credit rating and issue size. The presence of any relationship of Sukuk yields with these variables is tested using the ordinary least square (OLS) model. This analysis will provide an understanding of the factors that significantly affect Sukuk yields. This will help investors and issuers improve their investment decisions and minimize the perceived risks in Sukuk markets. This study will contribute to the existing literature on Sukuk by providing fresh evidence on the determinants of Sukuk yields.

\section{LITERATURE REVIEW}

Only a few studies have examined the determinants of Sukuk yields in the Sukuk market. Ang and Piazzesi (2001), under the asset pricing model, determined the influences of inflation and 
real economic activity on the yield curve and found that including inflation and real activity is useful in predicting the yield curve's movement. Saad and Mohamad (2012) examined the performance of 49 listed companies that issued Sukuk for the period 2005-2010 to investigate the relationship between Sukuk yields and their features (types of Sukuk, issuance, tenure, rating and payment) by using a multivariate regression model. Their results showed that Sukuk features are important in explaining Sukuk yields. Rahmana et al. (2013) highlight the factors that influence Sukuk yield spreads by employing the GARCH model to document evidence of Sukuk spreads and volatility. They found that changes in Sukuk spreads are negatively related to interest rates and the slope of the yield curve. Fathurahman and Fitriati (2013) analysed the ratio between the yield to maturity on Sukuk and conventional bonds listed on the Indonesian stock market. They found that the average of the Sukuk and conventional bonds significantly differ overall, and that the average of the Sukuk yield to maturity is greater than conventional bonds in three out of the ten groups studied. Ariff et al. (2013) show a significant difference between the yields of Sukuk and conventional bonds of the same issuers for the same term and rating. Granger causality tests show no causality between the yields of these two types of bonds. Naifar and Mseddi (2013) examined the determinants of Sukuk yield spreads using a regression technique for equity market variables and macroeconomic variables. They found that the model is well specified with explanatory power of more than $47 \%$, and that it has several implications for investors, risk managers and the development of Islamic financial markets. Said and Grassa (2013) examined the influence of economic and macroeconomic factors, global financial crises, financial systems, institutional environments, legal origins and religion and social factors on the 
development of the Sukuk market over the period 2003-2012 for Saudi Arabia, Kuwait, UAE, Bahrain, Qatar, Indonesia, Malaysia, Brunei, Pakistan, and Gambia. They found that the quality of regulatory and macroeconomic factors (GDP, economic size, trade openness, and percentage of Muslims) have a positive influence on the development of the Sukuk market. The financial crisis was found to have a significant negative effect as the total number of Sukuk issued in those years declined significantly. Saad et al. (2014) used a multivariate regression method to investigate the relationship between the main characteristics of Sukuk issuances (tenure, price, coupon, payment style, rating, producer price index and the issue size) and Sukuk yields and listed issuers (weighted average cost of capital), which is considered to be a new model representing risk. Their sample consists of 104 listed firms in Malaysia

covering the period 2002-2012 from the RAM newsletters and Bank Negara Malaysia's bond information hub. Their results show that only tenure, coupon and producer price index showed a significant relationship with Sukuk yields and risks. So, yields have a relationship of up to a $10 \%$ confidence level with five out of nine variables (tenure, coupon rates, payment styles, producer price index and sales growth). Alternatively, the weighted average cost of capital shows that six out of nine variables were significant, also at a 10\% confidence level (tenure, coupon rate, $\log$ size of issuances, producer price index and assets growth).

From the conventional bonds side, many studies have examined the determinants of bonds from different angles. Min (1998) examined the major macroeconomic variables that determined bond yield spreads in emerging markets. His result reported that strong macroeconomic fundamentals in a country - such as increased foreign assets, low domestic inflation rates and 
improved terms of trade - were associated with lower yield spreads. Whereas higher yield spreads are associated with weak liquidity variables, a high debt service ratio, a low export and a high import growth rate, a low ratio of foreign reserves to GDP, and a high debt to GDP ratio. Batten et al. (2006) determine the extent factors that affect the changes in credit spreads by examining the yield spread between the sovereign bonds issued in international markets in China, Korea, Malaysia, Philippines and Thailand, matched with near-maturity benchmark U.S. Treasury bonds of 2-, 5- and 10-year maturities. They found that the country's growth rate, interest rates, inflation rate and stock market are the main independent variables to the changes of bond yield spreads. Siklos (2011) examines the determinants of bond yield spreads in emerging markets, using domestic, external and global factors. He found that two common factors in all countries are volatility and central bank transparency, which depend on the geographic location of the emerging markets. Comelli (2012) used a set of country-specific and global factors to determine sovereign bond yield spreads for 28 emerging market economies. He found that the country-specific and global explanatory variables on bond yield spreads vary

across time and regions. Bengoechea (2012) tested the relationship of sovereign bond yields spreads and macroeconomic variables in the Eurozone. He found no constant relationships between macroeconomic variables and sovereign bond yield spreads. Cheikh and Amadou (2013) studied the determinants of US interest rates on emerging markets bond spreads. They found a negative relationship between US interest rates and emerging market bond spreads. Chowdhury et al. (2013) examined the determinants of emerging markets bond indexes by using regression analysis consisting of a fixed-effect 
model and a random-effect model. They found a positive relationship between bond index spreads, foreign direct investment and inflation, and a negative relationship between bond index spreads, GDP and reserves in total external debt.

\section{The Term Structure of Interest Rate and Yield Curve}

Interest rates on government bonds are very important as they are considered to be the benchmark of the financial system. The relationship between interest rates in the market and their maturities is known as the term structure of interest rates. A diagram displaying the term structure of the interest rates of a particular country at a particular point in time is called the yield curve of that financial system. The yield curve is considered to be an important tool. Any changes in the slope and level of the yield curve could potentially signal changes in expectations about inflation, interest rates and economic activity. Hence, it is followed by market practitioners to stay a step ahead of their competitors. The shape of the yield curve reflects the market's expectation for interest rates and potential changes in monetary policy, which makes the term structure of interest rates very important to investors and other participants in financial markets. The term structure is also used to identify differences in the theoretical value of securities relative to their market value. It can also be used to set a coupon rate on new bond issues and others financial securities. 
Figure 1 Common Shapes of Yield Curves

Source: Nos'hy and Rofael (2008, p.6).

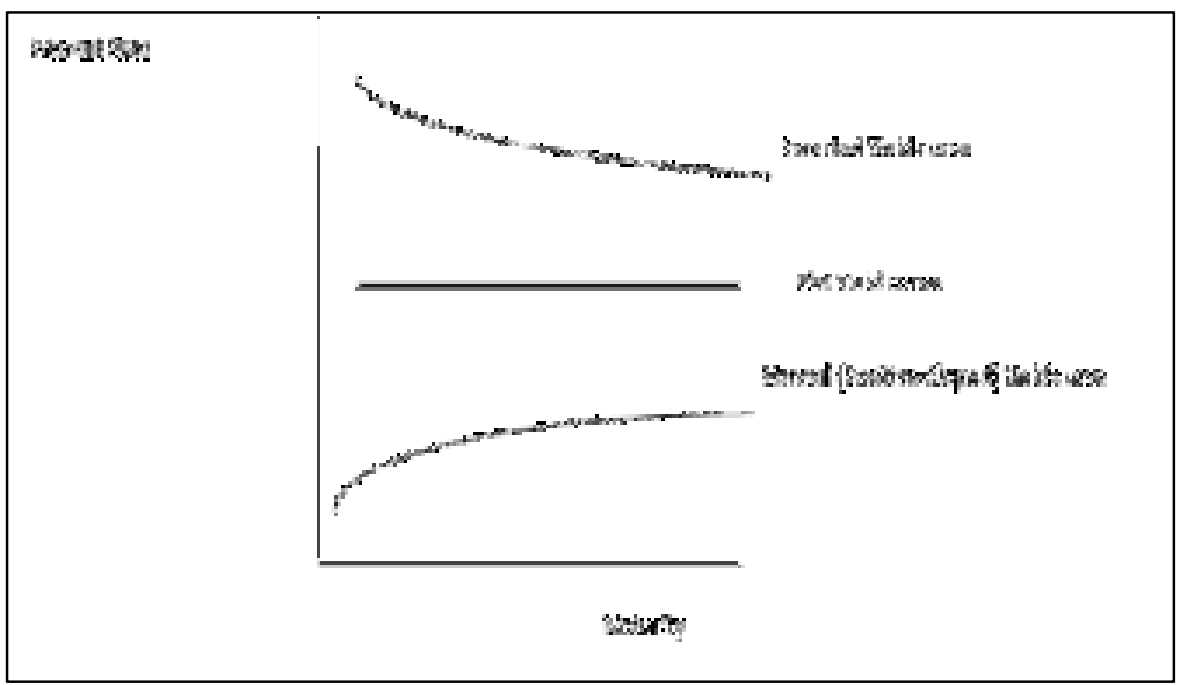

The yield curve can have several shapes depending on the sentiments in the market. The shape of the yield curve is influenced by interest rate expectations and is determined by economic fundamentals and technical factors. The economic fundamentals are expectations hypotheses, liquidity preference hypotheses and market segmentation hypotheses, which will be explained later in this chapter. The technical factors are market sentiments, demand of risk-free bonds at any particular maturity and the supply of bonds at any particular maturity. Figure 1 shows the different shapes of yield curves.

The yield curve will be upwards-sloping when the long-term interest rates are above the short-term interest rates, and this shape is considered to be the most common types of yield curve. It reflects investor expectations for the economy to grow in the 
future (positive slope). A flat yield curve is observed when longterm and short-term interest rates are the same. This is a signal of uncertainty in the economic outlook. Finally, a yield curve will be downwards-sloping when long-term interest rates are less than short-term interest rates. This indicates a worsening

economic situation when investors seek protection in safehaven government bonds. This also implies that inflation is likely to remain low in future. Under this abnormal situation, long-term investors think that in the future the economy will grow slowly and they will settle for lower yields.

\subsubsection{Theories of Term Structure of Interest Rates}

Different theories have been developed about the term structure of interest rates that explain the relationship between the interest rate and maturity of bonds. The main theories that tend to explain the term structure of interest rates are the expectations theory, liquidity preference hypothesis, the segmented markets theory and the preferred-habitat theory.

\subsubsection{The Expectations Theory}

The main logic behind the expectations theory is that investors' expectations about inflation are the major determinants of the yield curve, assuming that bonds of different maturities are perfect substitutes. The long-term interest rate is an average of the current-plus-expected future short-term rates. For example, the yield curve will be climbing when investors' expectations about future interest rates are rising (Russell, 1992).

\subsubsection{The Liquidity Premium Theory and Preferred Habitat Theory}

The liquidity premium theory and preferred habitat theory explain why long-term rates are almost always higher than short-term rates, and why the shape of the curve is often dependent on the short-term interest rate. The liquidity premium 
theory is also known as the Biased Expectations Theory, as it accepts the basic intuition underlying the pure expectations theory, except that long-term bonds carry a higher risk of fluctuation compared to short-term bonds (Irturk, 2006).

A similar conclusion by the preferred habitat theory through slightly different reasoning is that short-term bonds are preferred by investors who are interested in increasing liquidity and decreasing interest-rate risk (upwards-sloping yield curve). Therefore, if the long-term bonds pay the same return on shortterm bonds during the maturity dates, no one will tend to have

long-term bonds. It is well known that investors prefer to increase liquidity, and that long-term rates are normally higher than short-term rates, and therefore do not need to provide sufficient premium to attract long-term investment.

\subsubsection{The Market Segmentation Theory}

The market segmentation theory states that markets of bonds for different maturities are separated and divided, assuming that the markets are segmented when investors are expected to have a personal preference holding period.

In other words, the bond market is segmented by maturity range and there are no spill-over effects between each market segment. The yield curve is therefore determined by supply and demand conditions in each market segment without reference to conditions in other segments (Irturk, 2006).

Tables 1 and 2 show the maturity and yield to maturity measures of Sukuk and conventional bonds index of investment-grade fixed income securities. Specifically, the yield to maturity column shows an increase in the presenting yield to maturity for both indexes, from $1.79 \%$ for $1-3$ years to 4.93 for $10+$ years for Sukuk yield to maturity and from $0.49 \%$ for $1-3$ years to 2.03 for $10+$ years for conventional bonds' yield to maturity. On the 
other hand, it can be seen that Sukuk have a higher percentage of yield to maturity compared to conventional bonds.

Table 1 Sukuk Index Profile

\begin{tabular}{|c|c|c|c|c|c|c|c|c|c|}
\hline Description & $\begin{array}{l}\text { \#of } \\
\text { Issues }\end{array}$ & $\begin{array}{c}\text { Par } \\
\text { Amount' }\end{array}$ & $\begin{array}{l}\text { Market } \\
\text { Value' }\end{array}$ & $\begin{array}{c}\text { Market } \\
\text { Weight(\%) }\end{array}$ & $\begin{array}{l}\text { Average } \\
\text { Coupon (Y) }\end{array}$ & $\begin{array}{c}\text { Average Liffe } \\
\text { (Years) }\end{array}$ & $\begin{array}{l}\text { Yield to } \\
\text { Maturity (\%) }\end{array}$ & $\begin{array}{l}\text { Elfective } \\
\text { Duration }\end{array}$ & $\begin{array}{l}\text { OAS } \\
\text { (bPS) }\end{array}$ \\
\hline Sukuk Index & 65 & 53.19 & 55.53 & 100,00 & 3.64 & 5.36 & 2.58 & 4.37 & 123 \\
\hline 1.3 Years & 27 & 18.89 & 19.61 & 36.32 & 3.42 & 2.16 & 1.79 & 1.94 & 92 \\
\hline 3.5 Years & 22 & 18.55 & 19.35 & 34.85 & 3.46 & 4.01 & 2.50 & 3.73 & 117 \\
\hline 5.7 Years & 3 & 1.90 & 2.02 & 3.63 & 4.25 & 6.12 & 3.37 & 5.35 & 169 \\
\hline $7 \cdot 10$ Years & 11 & 11.85 & 12.39 & 22.31 & 3.89 & 8.55 & 3.42 & 7.23 & 151 \\
\hline $10+$ Years & 2 & 200 & 2.16 & 3.89 & 5.28 & 28.52 & 4.93 & 14.78 & 261 \\
\hline Government & 23 & 25.30 & 26.20 & 47.17 & 3.14 & 4.77 & 2.41 & 4.20 & 104 \\
\hline Regonal Govermment & 1 & 0.50 & 0.53 & 0.95 & 3.30 & 3.56 & 205 & 3.33 & 78 \\
\hline Corporate & 41 & 27.39 & 28.81 & 51.87 & 4.11 & 5.94 & 2.75 & 4.54 & 142 \\
\hline
\end{tabular}

Source: Citigroup index (2015, p.1).

Table 1 The Conventional Bonds Index Profile

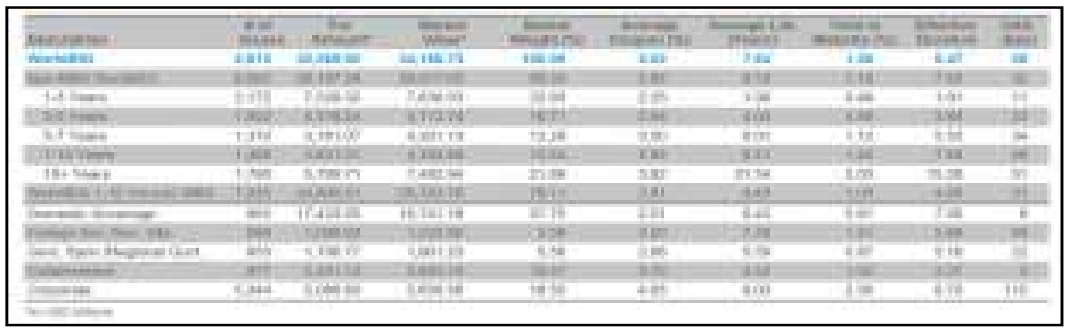

Source: Citigroup index (2015, p.1). 
Figure 2 presents the yield curves of Sukuk and conventional bonds' fixed income securities index as on 31/03/2015.

Source: Citigroup Index (2015).

A comparison of the yield curves of Sukuk and conventional Figure 2 The Yield Curve of Global Fixed Income Securities Index (Sukuk vs. Conventional)

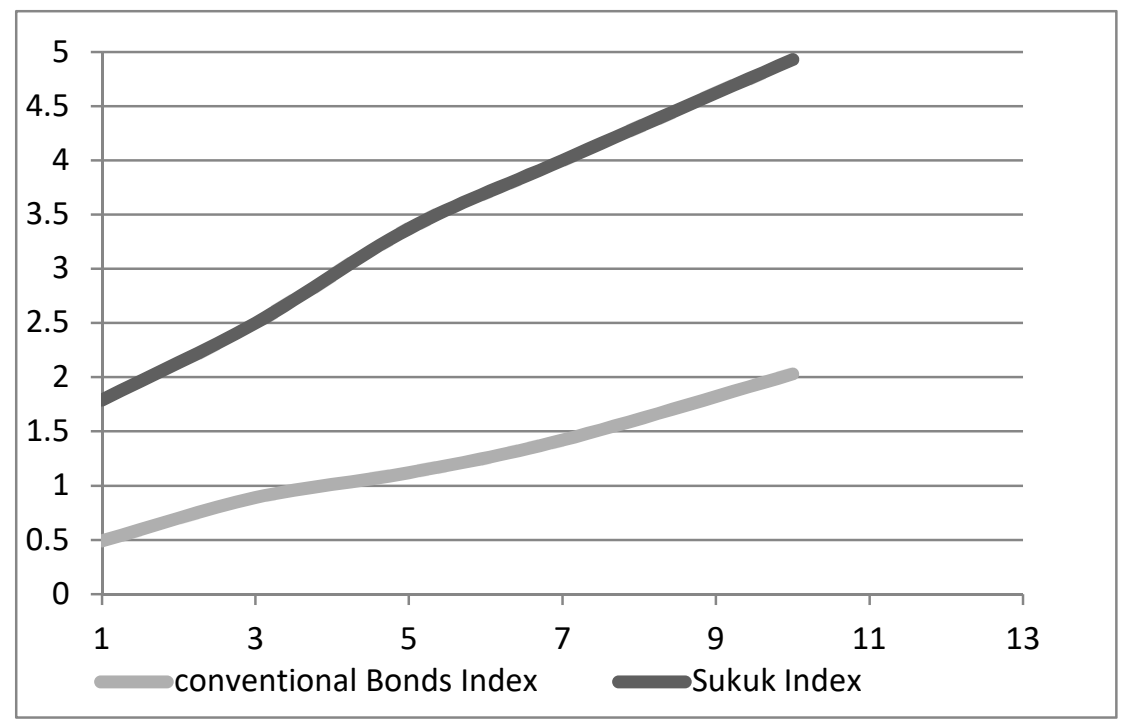

bonds' fixed income securities index shows normal upwardssloping yield curves. The yield to maturity on Sukuk is higher than for conventional bonds at all maturities. It seems to follow the expectations hypothesis, as future interest rates are expected to rise, then the yield curve slopes upwards, with longer-term bonds paying higher yields. 


\section{RESEARCH METHODOLOGY}

\subsection{Regression Analysis}

Regression analysis is a statistical procedure for estimating the relationships between variables. It focuses on the relationship between a dependent variable and one or more independent variables.

\subsubsection{Ordinary least squares regression method (OLS)}

The ordinary least squares regression method (OLS) is a statistical technique used to fit a function with data. In other words, it is used to find the best fit for a function with data by minimising the sum of the squared errors in the data. Single or multiple explanatory variables can be applied in this technique. The OLS regression model shows the relationship between two variables as follows:

$\mathrm{Y}=\mathrm{a}+b x+\varepsilon$ (Eq.1)

Where: $\mathrm{Y}=$ dependent variable; $\mathrm{X}=$ independent variable; $\mathrm{a}=$ intercept of regression line; $b=$ slope of regression line; $\varepsilon=$ error term.

This equation shows that $\mathrm{Y}$ is dependent on $\mathrm{X}$ and the slope $\mathrm{b}$ indicates the unit changes in $\mathrm{Y}$ for every unit change in $\mathrm{X}$.

However, by adding additional variables to the OLS regression equation, it can be extended to include multiple explanatory variables:

\subsubsection{Multiple OLS regression}

A multiple OLS regression is one of the most common models in business and economics used to model the relationship between a series of independent variables and a dependent variable. This allows the analyst to control the multiple factors that at the same time affect a dependent variable. 
$y=a+b_{1} x_{1}+b_{2} x_{2}+b_{3} x_{3}+\cdots+b_{m} x_{m}+$

E....................................... (Eq.2)

While the OLS regression equation is estimated as follows:

$E(y)=a+b_{1} x_{1}+b_{2} x_{2}+b_{3} x_{3}+\cdots+$

$b_{m} x_{m}$

The parameters ( $\alpha$ and $b$ ) from the multiple OLS regression equation are the same as for the OLS regression equation, where the relationship in the multiple OLS cannot be graphed on a single scatter plot. The variable (Y) is also the same as the OLS regression equation, but this time $\mathrm{Y}$ is predicted by multiple explanatory variables $\left(x_{1}\right.$ to $\left.x_{m}\right)$, and coefficients $b_{1}$ to $b_{m}=$ are slope coefficients.

The OLS regression model should follow the hypothesis of the classical regression, as the error-term value of the mean is zero, independent and must be normally distributed, without any heteroscedasticity problems, multicollinearity problems, autocorrelation and or specification bias (Gujarati \& Porter, 2009).

\subsubsection{Multicollinearity}

Multicollinearity in multiple regression analysis refers to correlation among independent variables, which can show how well the entire bundle of predictors predicts the outcome variable but may not give valid results about which individual predictor analysts are terminated with respect to others, as it difficult to determine which independent variables influence the dependent variable. Multicollinearity results in the independent variable being insignificant in explaining the dependent variable (Gujarati \& Porter, 2009).

The multicollinearity problem can be detected by examining the adjusted R-squared $\left(R^{2}\right)$ and variance inflation factor (VIF). If $R^{2}$ is high and VIF is larger than 10 for the independent variables, multicollinearity is probably an issue. 
Several methods can be used to avoid multicollinearity problems in multiple regression analysis, such as deleting one of the explanatory variables, which may help to produce a model with significant coefficients. Other solutions are avoiding falling into the dummy variable trap or avoiding including a constant term in the regression, which together guarantees perfect multicollinearity. More data can also be gathered (if possible) to produce more detailed parameter estimates with lower standard errors (Baguley, 2012).

\subsubsection{Data and Model Estimations}

The primary purpose of this study is to determine the yields of Sukuk. The bond determinants are maturity, size, risks, type of bond, credit rating and the nature of the bonds.

Quantitative data is employed here in order to determine the cause and effect relationships easily. The following table (3) presents the preliminary data on 36 Sukuk included in this analysis. The sample size is reduced due to the data availability for all of the relevant variables. Data were collected from Thomson Reuters DataStream.

Table 2 Preliminary Data for Sukuk

\begin{tabular}{|c|c|c|c|c|c|c|c|c|c|c|c|c|c|c|}
\hline SUKUK & Ytm & $\mathrm{m}$ & $\mathrm{Sz}$ & $\mathbf{r}$ & $\mathrm{t1}$ & $\mathbf{t 2}$ & $\mathbf{t 3}$ & $\mathbf{t 4}$ & $\mathbf{t 5}$ & $\mathbf{s c 1}$ & $\mathrm{sc2}$ & $\mathrm{rt1}$ & $\mathrm{rt2}$ & $\mathrm{rt3}$ \\
\hline DAR AI Arkan Sukuk & 6.39 & 5 & 13.02 & 0.002 & 1 & 0 & 0 & 0 & 0 & 0 & 1 & 0 & 0 & 0 \\
\hline Saudi Electricity & 3.71 & 10 & 13.82 & 0.004 & 1 & 0 & 0 & 0 & 0 & 0 & 1 & 0 & 1 & 0 \\
\hline Saudi Electricity & 5.39 & 30 & 13.82 & 0.011 & 1 & 0 & 0 & 0 & 0 & 0 & 1 & 1 & 0 & 0 \\
\hline Saudi Electricity & 1.95 & 4 & 13.12 & 0.001 & 1 & 0 & 0 & 0 & 0 & 0 & 1 & 1 & 0 & 0 \\
\hline Saudi Electricity & 3.64 & 9 & 13.82 & 0.002 & 1 & 0 & 0 & 0 & 0 & 0 & 1 & 1 & 0 & 0 \\
\hline DAR Al-Arkan International & 7.53 & 2 & 13.02 & 0.008 & 1 & 0 & 0 & 0 & 0 & 0 & 1 & 0 & 1 & 0 \\
\hline BSF Sukuk Limited & 3.11 & 4 & 13.53 & 0.004 & 0 & 0 & 0 & 1 & 0 & 0 & 1 & 1 & 0 & 0 \\
\hline CBB International Sukuk Company & 2.07 & 5 & 13.53 & 0.003 & 1 & 0 & 0 & 0 & 0 & 0 & 1 & 0 & 1 & 0 \\
\hline CBB International & 3.77 & 4 & 13.53 & 0.005 & 1 & 0 & 0 & 0 & 0 & 0 & 1 & 0 & 1 & 0 \\
\hline Adcb Islamic Finance & 2.41 & 3 & 13.12 & 0.003 & 0 & 0 & 0 & 0 & 1 & 0 & 1 & 1 & 0 & 0 \\
\hline
\end{tabular}


The Determinants of Sukuk

Dr. Hebah Shafeq Shalhoob 5/6/2018

\begin{tabular}{|c|c|c|c|c|c|c|c|c|c|c|c|c|c|c|}
\hline SUKUK & Ytm & $\mathbf{m}$ & $\mathbf{S z}$ & $\mathbf{r}$ & t1 & t2 & t3 & t4 & t5 & sc1 & $\operatorname{sc2} 2$ & rt1 & rt2 & rt3 \\
\hline DP World Sukuk Limited & 3.67 & 4 & 13.82 & 0.014 & 0 & 0 & 1 & 0 & 0 & 0 & 1 & 0 & 0 & 1 \\
\hline Dubai DOF Sukuk & 2.39 & 1 & 13.82 & 0.006 & 1 & 0 & 0 & 0 & 0 & 1 & 0 & 0 & 0 & 1 \\
\hline Dubai DOF Sukuk & 3.67 & 4 & 13.30 & 0.002 & 1 & 0 & 0 & 0 & 0 & 1 & 0 & 0 & 0 & 1 \\
\hline Dubai DOF Sukuk & 5.18 & 9 & 13.38 & 0.003 & 1 & 0 & 0 & 0 & 0 & 1 & 0 & 0 & 0 & 1 \\
\hline Tdic Sukuk Limited & 1.46 & 1 & 13.82 & 0.005 & 1 & 0 & 0 & 0 & 0 & 1 & 0 & 1 & 0 & 0 \\
\hline MAF Sukuk Limited & 3.70 & 4 & 12.90 & 0.011 & 0 & 0 & 0 & 1 & 0 & 0 & 1 & 0 & 1 & 0 \\
\hline Jafz SUK 2019 Limited & 4.98 & 6 & 13.38 & 0.002 & 0 & 1 & 0 & 0 & 0 & 0 & 1 & 0 & 0 & 1 \\
\hline EIB Sukuk Company & 3.22 & 4 & 13.12 & 0.002 & 0 & 1 & 0 & 0 & 0 & 0 & 1 & 0 & 0 & 1 \\
\hline EIB SUKUK & 3.99 & 5 & 13.12 & 0.002 & 0 & 1 & 0 & 0 & 0 & 0 & 1 & 0 & 0 & 1 \\
\hline HILAL SUKUK & 1.50 & 1 & 11.51 & 0.001 & 0 & 0 & 0 & 1 & 0 & 0 & 1 & 0 & 0 & 1 \\
\hline FGB Sukuk Company Limited & 2.32 & 3 & 13.38 & 0.006 & 0 & 0 & 0 & 0 & 1 & 0 & 1 & 0 & 0 & 1 \\
\hline FGB Sukuk Company Limited & 2.38 & 4 & 13.12 & 0.008 & 0 & 0 & 0 & 0 & 1 & 0 & 1 & 0 & 0 & 1 \\
\hline Hbme Sukuk Company & 2.24 & 3 & 13.12 & 0.004 & 0 & 0 & 0 & 0 & 1 & 0 & 1 & 0 & 0 & 1 \\
\hline SIB Sukuk & 2.84 & 3 & 12.90 & 0.006 & 0 & 0 & 0 & 1 & 0 & 0 & 1 & 0 & 1 & 0 \\
\hline KT Sukuk Varlik & 3.87 & 3 & 12.77 & 0.004 & 0 & 0 & 0 & 0 & 1 & 0 & 1 & 0 & 0 & 1 \\
\hline 1MALAYSIA Sukuk Global & 1.37 & 2 & 13.82 & 0.005 & 1 & $\mathbf{0}$ & 0 & 0 & 0 & 1 & 0 & 1 & 0 & $\mathbf{0}$ \\
\hline Petronas Global Sukuk & 1.23 & 1 & 13.82 & 0.004 & 1 & 0 & 0 & 0 & 0 & 0 & 1 & 0 & 0 & 1 \\
\hline 1MALAYSIA Sukuk Global & 1.56 & 1 & 13.82 & 0.003 & 1 & 0 & 0 & 0 & 0 & 1 & 0 & 1 & 0 & 0 \\
\hline Wakala Global Sukuk & 1.67 & 3 & 13.82 & 0.002 & 0 & 0 & 0 & 1 & 0 & 1 & 0 & 1 & 0 & 0 \\
\hline Wakala Global Sukuk & 3.87 & 8 & 13.59 & 0.005 & 0 & 0 & 0 & 1 & 0 & 1 & 0 & 1 & 0 & 0 \\
\hline QIB Sukuk Funding & 2.06 & 1 & 13.53 & 0.002 & 1 & 0 & 0 & 0 & 0 & 0 & 1 & 0 & 0 & 1 \\
\hline Qiib Sukuk Funding Limited & 3.21 & 4 & 13.53 & 0.003 & 1 & 0 & 0 & 0 & 0 & 0 & 1 & 0 & 0 & 1 \\
\hline Pakistan Sukuk 1 & 10.13 & 23 & 12.61 & 0.011 & 0 & 0 & 0 & 0 & 1 & 1 & 0 & 0 & 1 & 0 \\
\hline Pakistan Sukuk 2 & 8.99 & 3 & 13.12 & 0.011 & 0 & 0 & 0 & 0 & 1 & 1 & 0 & 0 & 1 & 0 \\
\hline Pakistan Sukuk 3 & 8.66 & 3 & 13.12 & 0.011 & 0 & 0 & 0 & 0 & 1 & 1 & 0 & 0 & 1 & 0 \\
\hline Pakistan Sukuk 4 & 8.54 & 4 & 13.53 & 0.011 & 0 & 0 & 0 & 0 & 1 & 1 & 0 & 0 & 1 & 0 \\
\hline
\end{tabular}

Source: Generated by the author 
The determination of Sukuk yield mostly depends on the studies conducted by Ang and Piazzesi (2001), Saad and Mohamad (2012), Rahmana et al. (2013), Naifar and Mseddi (2013), and Saad et al. (2014). Modelling the equation involves the factors that could determine the yield of Sukuk, including maturity, size, risks, type of bond (Ijara, Musharakah, Modarabah, Wakala and mixed), credit rating ( $\mathrm{A}$ is the highest grade, $\mathrm{B}$ rating is good grade, or NA is none available rating grade) and the nature of the bond (sovereign or corporate). The reasons behind the selection are: first, some of these variables are selected based on the literature review. Particular reference was made to Saad et al. (2014) (tenure, price, rating and the issue size), Said and Grassa (2013) (macroeconomic variables, indicators of the financial system, institutional quality, global financial crisis, market regulation, legal origin, religion and society) and Saad and Mohamad (2012) (types of Sukuk, issuance, tenure and rating). Second, this study aimed to choose all of the available economic factors that could be obtained from the data to run this test. However, in conventional bond literature, most studies use the major macroeconomic variables, such as gross domestic product (GDP), unemployment rate, and inflation rate. The definition and expected signP5FP5F ${ }^{1} \mathrm{PP}$ for each of the independent variables in this study are therefore explained as follows:

a) Sukuk maturity is positively related to Sukuk yield, as mentioned by Saad et al. (2014) in their results. The longer the maturity date, the higher yields.

\footnotetext{
1 The sign of the correlation coefficient defines the direction of the relationship, either positive or negative. A positive correlation coefficient means that as the value of one variable increases, the value of the other variable increases; as one decreases the other decreases. A negative correlation coefficient indicates that as one variable increases, the other decreases, and vice-versa.
} 
b) Sukuk size is positively related to Sukuk yield. It is measured as the value of bonds issuance to GDP, as mentioned by Saad et al. (2014) in their results.

c) Sukuk risks are positively related to Sukuk yield. The higher the risk, the higher the yield and therefore the higher the expected return.

d) Type of bonds is positively related to Sukuk yield, as is mentioned by Saad and Mohamad (2012) in their results. They found that Bai Bithaman Ajil generate a high yield compared to Murabahah Sukuk.

e) Credit rating is an assessment carried out by a private rating agency to indicate the level of risk. It assumes that credit rating is positively related to Sukuk yield, as is mentioned by Said and Grassa (2013). The higher the credit rating, the higher the yield and thus the expected return.

f) The relationship between the nature of the bonds and Sukuk yield looks to be unclear here. It examines whether sovereign or corporate Sukuk have an effect on Sukuk yield. Normally, corporate bonds are considered to have higher risk than government bonds.

The model derived from the multiple regression model analysis to see the impact of the different variables on Sukuk yields is as follows:

$Y T M=a+b_{1} m+b_{2} s z+b_{3} r+b_{4} t_{1}+b_{5} t_{2}+b_{6} t_{3}+b_{7} t_{4}+$ $b_{8} t_{5}+b_{9} s c_{1}+b_{10} s c_{2}+b_{11} r t_{1}+b_{12} r t_{2}+b_{13} r t_{3}+$ $\varepsilon$ ...(Eq.4)

Where: $\mathrm{YTM}=$ yield to maturity; $\mathrm{m}=$ maturity; $\mathrm{sz}=$ size; $\mathrm{r}=$ risk; $t_{1}=$ Ijara $; t_{2}=$ Musharakah; $t_{3}=$ Modarabah; $t_{4}=$ Wakala $; t_{5}=$ mix; $r t_{1}=\mathrm{A}$ credit rating; $r t_{2}=\mathrm{B}$ credit rating; $r t_{3}=\mathrm{NA}$ credit rating; $s c_{1}=$ sovereign bonds; $s c_{2}=$ corporate bonds; $\varepsilon=$ the 
stochastic error term; and coefficients $b_{1}$ to $b_{13}=$ are slope coefficients for all $n=13$.

The null and alternate hypotheses were developed to fit with the regression model:

$\mathrm{HRR}_{0} \mathrm{RR}$ : The maturity, size, risks, types of bonds, credit rating and the nature of the bonds have no impact on Sukuk yield.

$\mathrm{HRR}_{1} \mathrm{RR}$ : The maturity, size, risks, types of bonds, credit rating and the nature of the bonds have a significance impact on Sukuk yield.

The null hypothesis therefore states that there is no relationship between the dependent variable (Sukuk yield), and the independent variables (maturity, size, risks, types of bonds, credit rating and the nature of the bonds). It means that, if the null hypothesis is rejected, the overall relationship between the yields and the independent variables is significant, where at least one or more of the parameters are not equal to zero.

The multiple regressions are estimated through the OLS method, as the model fit tested by the coefficient, probability (t-tests), Fratio, $R^{2}$ value and the VIF will be biased. To reflect the strength and type of the relationship of the explanatory variables to the dependent variable, the coefficient for each explanatory variable is used. The positive coefficient sign implies a direct correlation while the negative implies an inverse relationship between the dependent and independent variables. In other words, to confirm the parameters effect on the existence of at least one of the dummy variable coefficients is statistically significant. The value of the dummy variables for the types of bonds $\left(t_{1}, t_{2}, t_{3}, t_{4}\right.$ and $\left.t_{5}\right)$, credit rating $\left(r t_{1}, r t_{2}\right.$ and $\left.r t_{3}\right)$ and the nature of the bonds $\left(s c_{1}\right.$ and $\left.s c_{2}\right)$ represent categorical variables of 0 and 1 where it is 1 if the criterion is satisfied and 0 if not. The t-test is used to assess each variable's assumption and its significance - in other words, to evaluate whether the 
individual independent variable is significant in explaining the changes in dependent variables. This means that the individual independent variable is significant when the p-value is smaller than the significance level or the t-test statistic value is smaller or greater than the critical value in influencing the dependent variable. The hypothesis testing for the t-test implies that:

$\mathrm{HRR}_{0} \mathrm{RR}: b_{1}=b_{2}=b_{3}=b_{4}=b_{5}=b_{6}=b_{7}=b_{8}=b_{9}=b_{10}=b_{11}$ $=b_{12}=b_{13}=0$

$\mathrm{HRR}_{1} \mathrm{RR}: b_{n} \neq 0$

where $n=1,2,3,4,5,6,7,8,9,10,11,12,13$.

The F-ratio is used to assess if the overall model is reliable and significant. In other words, it examines whether at least one of the independent variables or more independent variables are significant to the regression model. Therefore, if the p-value is smaller than the significance level, the null hypothesis is rejected. The hypothesis testing for the F-ratio implies that:

$\mathrm{HRR}_{0} \mathrm{RR}: b_{1}=b_{2}=b_{3}=b_{4}=b_{5}=b_{6}=b_{7}=b_{8}=b_{9}=b_{10}=b_{11}$ $=b_{12}=b_{13}$

$\mathrm{HRR}_{1} \mathrm{RR}$ : at least one of the $b_{n} \neq 0$

where $n=1,2,3,4,5,6,7,8,9,10,11,12,13$.

The VIF measures redundancy between explanatory variables and should be smaller than 10 for each of the independent variables. The adjusted $\mathrm{R}$-squared is used to correct the tendency for $R^{2}$ to approach for more than one independent variables.

\section{RESULTS}

Tables 4, 5, 6, 7 and 8 present the regression results of the relationship between the yields of Sukuk and the independent variable. In order to have a better understanding of this relationship, the regression analysis has been run four times: first, the model was run involving all 13 independent variables without including the constant. Second, the model was run involving the type of bonds (Ijarah, Musharaka, Modarabah, Wakala and mixed). Third, the model involves credit 
rating (A or B). And last, the model involves the nature of the bonds (Sovereign or Corporate). Hence, the reason for running the test 3 more times was to avoid the dummy variable trap.P6FP6 ${ }^{2} \mathrm{PP}$

\subsection{Results of the Model Involving All 13} Independent

Table 3 Model Summary of the OLS Regression Involving All 13 Independent

\begin{tabular}{|c|c|c|c|c|c|c|}
\hline Model & $\mathrm{R}$ & $R^{2}$ & $\operatorname{adj} R^{2}$ & \multicolumn{2}{|c|}{$\begin{array}{l}\text { Std. Error of the } \\
\text { Estimate }\end{array}$} & $\begin{array}{l}\text { Durbin- } \\
\text { Watson }\end{array}$ \\
\hline 1 & $.971 \mathrm{RR}_{\mathrm{a}}$ & .942 & .913 & \multicolumn{2}{|c|}{1.32639} & 1.446 \\
\hline Model & $\begin{array}{l}\text { Sum of } \\
\text { Squares }\end{array}$ & df & Mean Square & \multicolumn{2}{|c|}{$\mathrm{F}$} & Sig. \\
\hline Regression & 687.867 & 12 & 57.322 & \multirow{3}{*}{\multicolumn{2}{|c|}{32.582}} & $.000 \mathrm{RR}_{\mathrm{a}}$ \\
\hline Residual & 42.224 & 24 & 1.759 & & & \\
\hline Total & 730.090 & 36 & & & & \\
\hline Model & \multicolumn{2}{|c|}{$\begin{array}{c}\text { Unstandardized } \\
\text { Coefficients }\end{array}$} & $\begin{array}{c}\text { Standardized } \\
\text { Coefficients }\end{array}$ & \multirow[t]{2}{*}{ t-test } & \multirow[t]{2}{*}{ Sig. } & \multirow[t]{2}{*}{ VIF } \\
\hline & $\mathrm{B}$ & Std. Error & Beta & & & \\
\hline $\mathrm{m}$ & .120 & .047 & .203 & 2.558 & $.017 * *$ & 2.623 \\
\hline sz & -.880 & .676 & -2.608 & $\begin{array}{c}- \\
1.302\end{array}$ & .205 & $\begin{array}{c}1665.52 \\
7\end{array}$ \\
\hline $\mathrm{r}$ & 166.362 & 124.081 & .232 & 1.341 & .193 & 12.400 \\
\hline t1 & 16.925 & 8.887 & 2.583 & 1.904 & $.069^{*}$ & 763.231 \\
\hline $\mathrm{t} 2$ & 18.979 & 8.854 & 1.217 & 2.144 & $.042 * *$ & 133.683 \\
\hline t3 & 17.255 & 9.112 & .639 & 1.894 & $.070^{*}$ & 47.193 \\
\hline $\mathrm{t} 4$ & 16.076 & 8.484 & 1.457 & 1.895 & $.070^{*}$ & 245.472 \\
\hline t5 & 17.745 & 8.569 & 1.970 & 2.071 & $.049 * *$ & 375.645 \\
\hline $\mathrm{sc} 1$ & 1.517 & .534 & .194 & 2.841 & $\begin{array}{c}.0098^{* *} \\
*\end{array}$ & 1.945 \\
\hline $\mathrm{rt} 1$ & -4.326 & 1.520 & -.506 & $\begin{array}{c}- \\
2.846\end{array}$ & $.009^{* * *}$ & 13.137 \\
\hline $\mathrm{rt} 2$ & -2.141 & 1.529 & -.251 & $1 . \overline{400}$ & .174 & 13.290 \\
\hline $\mathrm{rt3}$ & -4.218 & 1.430 & -.605 & $2 . \overline{950}$ & $.007 * * *$ & 17.433 \\
\hline
\end{tabular}

${ }^{2}$ The dummy variable trap is a scenario in which the independent variables are highly correlated. 
a. Predictors: $\mathrm{rt} 3, \mathrm{rt} 2, \mathrm{rt} 1, \mathrm{t} 3, \mathrm{t} 2, \mathrm{t} 4, \mathrm{t} 5, \mathrm{sc} 1, \mathrm{~m}, \mathrm{r}, \mathrm{t} 1, \mathrm{sz}$. $* * *$ significant at $1 \%, * *$ significant at $5 \%$ and $*$ significant at $10 \%$.

Source: Generated by the author.

The OLS regression output shows that the $R^{2}$ value is $94 \%$, which is high for the estimated regression equation with these independent variables and the adj $R^{2}$ value is $91 \%$ as these results indicate a good fit of regression line in the data set. The Durbin-Watson statistic is less than 2, which is evidence of a positive serial correlation. The residual mean square of 1.759 also indicates a good fit and the value of the $F$ ratio is statistically significant. The F-ratio is 32.582 and the p-value is 0.0000 . The $\mathrm{p}$-value is smaller than 0.05 , which indicates that this model is significant at a $5 \%$ significance level. The $p$. values of the maturity, types of bonds, credit rating, NA credit rating and the nature of the bonds are significant at $1 \%, 5 \%$ and $10 \%$, and the null hypothesis is rejected. The $\mathrm{p}$. values of the size, risk and the $\mathrm{B}$ credit rating are insignificant at $1 \%, 5 \%$ and $10 \%$.

The estimated regression coefficient for the risk variable (166.362) is positive (highest) and insignificant at 1\%, 5\% and $10 \%$ significance levels, whereas the regression coefficient for the A credit rating dummy variable (-4.326) is negative (lowest) and statistically significant at the $1 \%$ significance level. The VIF for the size, risk, Ijarah, Musharakah, Modarabah, Wakala, mix Sukuk, A credit rating, $\mathrm{B}$ credit rating and NA credit rating are larger than 10 and, simultaneously, suggest that a high degree of multicollinearity is present.

In terms of the multicollinearity problem, Eq.4 shows a clear issue of multicollinearity.

$Y T M=a+b_{1} m+b_{2} s Z+b_{3} r+b_{4} t_{1}+b_{5} t_{2}+b_{6} t_{3}+b_{7} t_{4}+$ $b_{8} t_{5}+b_{9} s c_{1}+b_{10} s c_{2}+b_{11} r t_{1}+b_{12} r t_{2}+$

$\varepsilon$ (Eq.5) 
To resolve this problem, one of the independent variables will be excluded (n-1).

In this regard, this test has been runs 13 times, each time with one of the independent variables excluded until it was found that the exclusion of the last independent variable NA credit rating (rt3) and the inclusion of the constant was the best solution to avoid multicollinearity. This can be seen in the following table.

Table 4 Model Summary of the OLS Regression Involving

All 12 Independent

\begin{tabular}{|c|c|c|c|c|c|c|}
\hline & & & & \multirow{2}{*}{\multicolumn{2}{|c|}{$\begin{array}{l}\text { Std. Error of } \\
\text { the Estimate }\end{array}$}} & \\
\hline Model & $\mathrm{R}$ & R Square & $\operatorname{adj} R^{2}$ & & & $\begin{array}{l}\text { Durbin- } \\
\text { Watson }\end{array}$ \\
\hline 1 & $.839 a$ & .704 & .586 & \multicolumn{2}{|c|}{1.51700} & 1.392 \\
\hline Model & $\begin{array}{l}\text { Sum of } \\
\text { Squares }\end{array}$ & df & Mean Square & \multicolumn{2}{|c|}{$\mathrm{F}$} & Sig. \\
\hline $\begin{array}{l}\text { Regress } \\
\text { ion }\end{array}$ & 136.999 & 10 & & \multirow{3}{*}{\multicolumn{2}{|c|}{5.953}} & $.000 \mathrm{a}$ \\
\hline $\begin{array}{c}\text { Residua } \\
1\end{array}$ & 57.532 & 25 & 2.301 & & & \\
\hline Total & 194.531 & 35 & & & & \\
\hline \multirow[t]{2}{*}{ Model } & \multicolumn{2}{|c|}{$\begin{array}{c}\text { Unstandardized } \\
\text { Coefficients }\end{array}$} & $\begin{array}{l}\text { Standardized } \\
\text { Coefficients }\end{array}$ & \multirow{2}{*}{ t-test } & \multirow{2}{*}{ Sig. } & \multirow{2}{*}{ VIF } \\
\hline & B & Std. Error & Beta & & & \\
\hline $\begin{array}{c}\text { (Consta } \\
\text { nt) }\end{array}$ & 18.513 & 10.263 & & 1.804 & $.083 *$ & \\
\hline $\mathrm{m}$ & .126 & .053 & .310 & 2.367 & $\begin{array}{c}.026^{*} \\
*\end{array}$ & 1.451 \\
\hline sz & -1.169 & .765 & -.234 & $\begin{array}{c}- \\
1.528\end{array}$ & .139 & 1.978 \\
\hline $\mathrm{r}$ & 153.180 & 141.819 & .232 & 1.080 & .290 & 3.895 \\
\hline $\mathrm{t} 2$ & 1.519 & 1.025 & .181 & 1.483 & .151 & 1.255 \\
\hline t3 & .137 & 2.248 & .010 & .061 & .952 & 2.135 \\
\hline t4 & -1.168 & .894 & -.187 & $\begin{array}{c}- \\
1.306\end{array}$ & .203 & 1.737 \\
\hline t5 & .485 & .849 & .090 & .571 & .573 & 2.112 \\
\hline $\mathrm{sc} 2$ & -1.460 & .610 & -.296 & $\begin{array}{c}- \\
2.393\end{array}$ & $\begin{array}{c}.025^{*} \\
*\end{array}$ & 1.295 \\
\hline rt1 & -.346 & .801 & -.067 & -.432 & .669 & 2.014 \\
\hline $\mathrm{rt} 2$ & 1.836 & .825 & .354 & 2.226 & $\begin{array}{c}.035^{*} \\
*\end{array}$ & 2.135 \\
\hline
\end{tabular}


a. Predictors: $\mathrm{rt} 3, \mathrm{rt} 2, \mathrm{rt} 1, \mathrm{t} 3, \mathrm{t} 2, \mathrm{t} 4, \mathrm{t} 5, \mathrm{sc} 1, \mathrm{~m}, \mathrm{r}, \mathrm{t} 1, \mathrm{sz}$.

$* *$ significant at $5 \%$ and $*$ significant at $10 \%$.

Source: Generated by the author.

The OLS regression output shows that the $R^{2}$ value is $70 \%$, which is high for the estimated regression equation with these independent variables, and the adj $R^{2}$ value is $58 \%$ as these results indicate a good fit of regression line in the data set. The Durbin-Watson statistic is less than 2, which is evidence of a positive serial correlation. The error term (residual) is normally distributed with a mean close to zero and constant variance. The residual mean square of 2.30 also indicates a good fit and the value of the $\mathrm{F}$ ratio is statistically significant. The F-ratio is 5.953 and the p-value is 0.0000 . The p-value is smaller than 0.05 , which indicates that this model is significant at a $5 \%$ significance level.

The estimated regression coefficient for the risk variable (153.180) is positive (highest) and insignificant at the 5\% level, whereas the regression coefficient for a corporate bonds dummy variable (-1.460) is negative (lowest) and statistically significant at the $5 \%$ level. The null hypothesis in this model is that there is no significant linear correlation in the series. The $\mathrm{p}$-value from the result in most cases is greater than $5 \%$ and $10 \%$, and the null hypothesis is to be accepted. While in maturity, size, corporate Sukuk and B credit rating are significant at 5\% and 10\%, and the null hypothesis is rejected. The VIF for the variables are less than 5 , indicating that the multicollinearity problem has been solved. 


\subsection{Results of The Sukuk Types Effect}

Table 5 Model Summary of the Sukuk Types Effect

\begin{tabular}{|c|c|c|c|c|c|c|}
\hline Model & $\mathrm{R}$ & R Square & $\operatorname{adj} R^{2}$ & \multicolumn{2}{|c|}{$\begin{array}{l}\text { Std. Error of } \\
\text { the Estimate }\end{array}$} & $\begin{array}{l}\text { Durbin- } \\
\text { Watson }\end{array}$ \\
\hline 1 & $.432 \mathrm{a}$ & .186 & .081 & \multicolumn{2}{|c|}{2.25950} & 1.060 \\
\hline Model & $\begin{array}{l}\text { Sum of } \\
\text { Squares }\end{array}$ & df & Mean Square & \multicolumn{2}{|c|}{$\mathrm{F}$} & Sig. \\
\hline $\begin{array}{l}\text { Regres } \\
\text { sion }\end{array}$ & 36.265 & 4 & 9.066 & \multirow{3}{*}{\multicolumn{2}{|c|}{1.776}} & $.159 a$ \\
\hline $\begin{array}{l}\text { Residu } \\
\text { al }\end{array}$ & 158.266 & 31 & 5.105 & & & \\
\hline Total & 194.531 & 35 & & & & \\
\hline Model & \multicolumn{2}{|c|}{$\begin{array}{l}\text { Unstandardized } \\
\text { Coefficients }\end{array}$} & $\begin{array}{l}\text { Standardized } \\
\text { Coefficients }\end{array}$ & \multirow{2}{*}{ t-test } & \multirow{2}{*}{ Sig. } & \multirow{2}{*}{ VIF } \\
\hline & $\mathrm{B}$ & Std. Error & Beta & & & \\
\hline $\begin{array}{l}\text { (Const } \\
\text { ant) }\end{array}$ & 3.334 & .548 & & 6.085 & $\begin{array}{l}.000 \\
*\end{array}$ & \\
\hline $\mathrm{t} 2$ & .732 & 1.415 & .087 & .518 & .608 & 1.078 \\
\hline $\mathrm{t} 3$ & .345 & 2.325 & .024 & .148 & .883 & 1.029 \\
\hline $\mathrm{t} 4$ & -.550 & 1.073 & -.088 & -.512 & .612 & 1.127 \\
\hline t5 & 2.175 & .931 & .405 & 2.335 & $\begin{array}{c}.026 \\
* *\end{array}$ & 1.147 \\
\hline
\end{tabular}

a. Predictors: rt3, rt2, rt1, t3, t2, t4, t5, sc1, m, r, t1, sz.

$* *$ significant at $5 \%$ and $*$ significant at $1 \%$.

Source: Generated by the author.

The results from Table 6 show that the $R^{2}$ value is $19 \%$, which is low for the estimated regression equation for the types of the Sukuk effect and adj $R^{2}$ is $8 \%$ as these results indicate a bad fit of the regression line in the data set. The Durbin-Watson statistic is less than 2, which is evidence of a positive serial correlation. The error term (residual) is normally distributed with a mean close to zero and constant variance. The F-ratio is 1.776 and p-value is 0.159 . The p-value is higher than 0.05 , which indicates that this model is insignificant at $5 \%$ significance level. The estimated regression coefficient for the constant (3.334) is positive (highest) and statistically significant 
at the $1 \%$ level, whereas regression coefficient for Wakala dummy variable $(-0.550)$ is negative (lowest) and statistically not significant at the $5 \%$ or $1 \%$ significant level. The other dummy variables are positive and insignificant at the 5\% level for Musharakah, and Modarabah, where it is significant at 5\% for the mixed Sukuk. The VIF for the variables are less than 5, indicating no multicollinearity problem.

\subsection{Results of the Credit Rating Effect}

Table 6 Model Summary of the Credit Rating Effect

\begin{tabular}{|c|c|c|c|c|c|c|}
\hline Model & $\mathrm{R}$ & R Square & $\operatorname{adj} R^{2}$ & \multicolumn{2}{|c|}{$\begin{array}{l}\text { Std. Error of } \\
\text { the Estimate }\end{array}$} & $\begin{array}{c}\text { Durbin } \\
- \\
\text { Watso } \\
n\end{array}$ \\
\hline 1 & $.582 \mathrm{a}$ & .339 & 299 & \multicolumn{2}{|c|}{1.97365} & 1.516 \\
\hline Model & $\begin{array}{l}\text { Sum of } \\
\text { Squares }\end{array}$ & $\mathrm{df}$ & Mean Square & \multicolumn{2}{|c|}{$\mathrm{F}$} & Sig. \\
\hline $\begin{array}{c}\text { Regressio } \\
n\end{array}$ & 65.986 & 2 & 32.993 & \multirow{3}{*}{\multicolumn{2}{|c|}{8.470}} & $.001 \mathrm{a}$ \\
\hline Residual & 128.545 & 33 & 3.895 & & & \\
\hline Total & 194.531 & 35 & & & & \\
\hline \multirow[t]{2}{*}{ Model } & \multicolumn{2}{|c|}{$\begin{array}{l}\text { Unstandardized } \\
\text { Coefficients }\end{array}$} & $\begin{array}{l}\text { Standardized } \\
\text { Coefficients }\end{array}$ & \multirow{2}{*}{ t-test } & \multirow{2}{*}{ Sig. } & \multirow{2}{*}{ VIF } \\
\hline & B & $\begin{array}{l}\text { Std. } \\
\text { Error }\end{array}$ & Beta & & & \\
\hline (Constant) & 3.273 & .493 & & $\begin{array}{c}6.63 \\
4\end{array}$ & $\begin{array}{c}.00 \\
0\end{array}$ & \\
\hline $\mathrm{rt} 1$ & -.625 & .796 & -.120 & -.786 & $\begin{array}{c}.43 \\
8\end{array}$ & 1.174 \\
\hline $\mathrm{rt} 2$ & 2.727 & .796 & .525 & $\begin{array}{c}3.42 \\
7\end{array}$ & $\begin{array}{c}.00 \\
2\end{array}$ & 1.174 \\
\hline
\end{tabular}

a. Predictors: rt3, rt2, rt1, t3, t2, t4, t5, sc1, m, r, t1, sz. Source: Generated by the author.

The results from Table 7 show that the $R^{2}$ value is $33 \%$, which is low for the estimated regression equation for the credit rating effect and adj $R^{2}$ is $29 \%$ as these results indicate a bad fit of regression line in the data set. The Durbin-Watson statistic is less than 2, which is evidence of a positive serial correlation. The error term (residual) is normally distributed with a mean 
close to zero and constant variance. The F-ratio is 8.470 and the $\mathrm{p}$-value is 0.001 . The $\mathrm{p}$-value is smaller than 0.05 , which indicates that this model is significant at 5\% significance level. The estimated regression coefficient for the constant (3.273) is positive (highest) and statistically insignificant at $1 \%$ significant level; the regression coefficient for the $\mathrm{B}$ credit rating dummy variable $(-0.625)$ is negative (lowest) and statistically insignificant at $1 \%, 5 \%$ or $10 \%$ significance levels. The unrated Sukuk dummy variable (2.727) is positive and significant at the $1 \%$ significant level. The VIF for the variables are less than 5 , indicating no multicollinearity problem.

\subsection{Results of the Nature of Sukuk Effect}

Table 7 Model Summary of the Nature of Sukuk Effect

\begin{tabular}{|c|c|c|c|c|c|c|}
\hline Model & $\mathrm{R}$ & R Square & $\operatorname{adj} R^{2}$ & \multicolumn{2}{|c|}{$\begin{array}{l}\text { Std. Error of } \\
\text { the Estimate }\end{array}$} & $\begin{array}{l}\text { Durbin- } \\
\text { Watson } \\
\end{array}$ \\
\hline 1 & $.286 a$ & .082 & .055 & \multicolumn{2}{|c|}{2.29235} & .979 \\
\hline Model & $\begin{array}{l}\text { Sum of } \\
\text { Squares }\end{array}$ & $\mathrm{df}$ & Mean Square & \multicolumn{2}{|c|}{$\mathrm{F}$} & Sig. \\
\hline $\begin{array}{l}\text { Regress } \\
\text { ion }\end{array}$ & 15.866 & 1 & 15.866 & \multirow{3}{*}{\multicolumn{2}{|c|}{3.019}} & $.091 \mathrm{a}$ \\
\hline $\begin{array}{c}\text { Residua } \\
1\end{array}$ & 178.665 & 34 & 5.255 & & & \\
\hline Total & 194.531 & 35 & & & & \\
\hline \multirow[t]{2}{*}{ Model } & \multicolumn{2}{|c|}{$\begin{array}{c}\text { Unstandardized } \\
\text { Coefficients }\end{array}$} & $\begin{array}{l}\text { Standardized } \\
\text { Coefficients }\end{array}$ & \multirow{2}{*}{ t-test } & \multirow{2}{*}{ Sig. } & \multirow{2}{*}{ VIF } \\
\hline & B & Std. Error & Beta & & & \\
\hline $\begin{array}{c}\text { (Consta } \\
\text { nt) }\end{array}$ & 3.388 & .468 & & 7.240 & $\begin{array}{c}.000 \\
*\end{array}$ & \\
\hline $\mathrm{sc} 1$ & 1.408 & .810 & .286 & 1.738 & $\begin{array}{c}.091 \\
* *\end{array}$ & 1.000 \\
\hline
\end{tabular}

a. Predictors: $\mathrm{rt} 3, \mathrm{rt} 2, \mathrm{rt} 1, \mathrm{t} 3, \mathrm{t} 2, \mathrm{t} 4, \mathrm{t} 5, \mathrm{sc} 1, \mathrm{~m}, \mathrm{r}, \mathrm{t} 1, \mathrm{sz}$.

** significant at $10 \%$ and $*$ significant at $1 \%$.

Source: Generated by the author.

The results from Table 8 show that the $R^{2}$ value is $8 \%$, which is low for the estimated regression equation for the nature of 
Sukuk effect and adj $R^{2}$ is $5 \%$ as these results indicate a bad fit of regression line in the data set. The Durbin-Watson statistic is less than 2, which is evidence of a positive serial correlation. The error term (residual) is normally distributed with a mean close to zero and constant variance. The F-ratio is 3.019 and the $\mathrm{p}$-value is 0.091 . The $\mathrm{p}$-value is smaller than 0.1 , which indicates that this model is significant at a $10 \%$ significance level. The estimated regression coefficient for the constant (3.388) is positive (highest) and statistically significant at the $1 \%$ significant level, whereas the regression coefficient for the sovereign dummy variable (1.408) is positive (lowest) and statistically significant at the $10 \%$ significant level. The VIF for the variables is less than 5 , indicating no multicollinearity problem.

\section{DISCUSSION OF THE RESULTS}

The results generated from the OLS regression analysis present the relationship between factors such as maturity, size, risks, type of bonds, credit rating and the nature of bonds and Sukuk yield.

The first independent variable is maturity. Bond maturities are different, such as short-term bonds maturities for 5 years or less, medium-term bond maturities that have a maturity period between 5 to 10 years, and long-term bond maturities that are usually 10 years or above. In general, the longer the time to maturity, the greater its yield rate due to the risks associated with time. This relationship is called the term structure of interest rates. Ariff and Safari (2013) examined the differences between the yields of Sukuk and conventional bonds for different maturities ranging from 3 months to 20 years. They suggest that with long-term maturities (15 or 20 years), Sukuk yield is lower than conventional bonds, while it is higher than conventional bonds with maturities of less than 10 years. Based 
on the result of the OLS regression involving all 13 independents, and the result of the OLS regression involving all 12 independents after solving the multicollinearity problem, Sukuk maturity is found to be significantly positively related to Sukuk yield. This result is consistent with the findings of Saad et al. (2014) which suggested that Sukuk maturity is positively related to Sukuk yield.

The second independent variable is size. Size is measured as the value of bond issuance to GDP as it is always described in the literature (Said and Grassa, 2013). According to Saad et al. (2014), the size of Sukuk issuance increased considerably, generating revenues in both the public and private sectors. The result of the OLS analysis involving all 13 independents and the result of the OLS analysis involving all 12 independents after solving the multicollinearity problem shows that Sukuk size is insignificantly negatively related to Sukuk yield. This result is inconsistent with the findings of Said and Grassa (2013) and Saad et al. (2014) where Sukuk size was found to have a significant positive impact on the yields and risks of the Sukuk market. Ahmad and Radzi (2011) also found that Sukuk performance rises when the GDP of the Sukuk-issuing country increases, while the performance of the Sukuk will decline when the GDP of the Sukuk-issuing country decreases. Similarly, Elkarim (2012) posits a significant correlation between GDP and the performance of conventional bonds. However, the result in this study regarding Sukuk size is inconsistent with the theory of supply and demand whereby any increase in size will allow demand for the bond to rise, as increasing the economy generates more wealth for the population.

The third independent variable is risk. Bond returns are dependent on several variables, including different types of risk. The main risk in the bond market is interest rate risk. Therefore, 
if interest-rate risks rise (higher risk), the bond yield also increases, raising the expected return. Haral (2010) stressed that the identification of the risks associated with Sukuk in developing and managing Sukuk markets is essential. Al-Amine (2012) suggested that any decrease in interest-rate risk leads Sukuk returns to increase. Nanaeva (2010) proposed that Sukuk and conventional bonds have different levels of risk. The result of the OLS regression involving all 13 independents and the

result of the result of the OLS regression involving all 12 independents after solving the multicollinearity problem shows that Sukuk risk is insignificantly and positively related to Sukuk yield. This result is inconsistent with the findings of Abdul Rauf (2014) who found a significant impact of market risk, credit risk, operational risk and liquidity risk on the total Sukuk returns.

The fourth independent variable is the effect of Sukuk type. There are different types of Sukuk contract, as described above, that comply with Islamic principles and standards in the capital market. Based on the results of the OLS analysis involving all 13 independent variables, it is found that all Sukuk types (Ijara, Musharakah, Modarabah, Wakala and mixed Sukuk) are significantly positively related to Sukuk yield. In terms of their relationship to Sukuk yield, the results of the OLS analysis involving all 12 independent variables are insignificantly positive for Musharakah, Modarabah and mixed Sukuk, and insignificantly negative for Wakala. Also, the results of the Sukuk-type effects show Musharakah and Modarabah to be insignificantly positive related to Sukuk yield, with Wakala having an insignificantly negative impact, and mixed Sukuk a significant positive impact. Saad and Mohamad (2012) suggested that Sukuk type is positively related to Sukuk yield. 
They found that Bai Bithaman Ajil generate a higher yield than Murabahah Sukuk. Godlewski et al. (2014) also investigated the influence of Sukuk type (Ijara, Mudarabah and Murabahah) on the stock market reaction to their issuance. They found that issuing Ijara Sukuk is significantly more positive across most estimations compared to other Sukuk structures such as Musharaka or Mudaraba. Mudaraba and Murabaha are not significant in all estimations as investors do not react differently to these types of Sukuk. Ariff and Safari (2013) also found that Ijara Sukuk have a significant effect on the risk behaviour of the issuing company.

The fifth independent variable is credit rating (A, B or NA). This refers to an assessment done by a private rating agency such as Standard \& Poor's or Moody's to indicate the level of risk. Interest rates are factored in to determine the creditworthiness of the issuer. Based on the result of the OLS involving all 13 independents, the credit ratings for A and NA-rated Sukuk are significantly negative related to Sukuk yield. The result of the B credit rating is insignificantly negative related to the Sukuk yield. In contrast, the result of the OLS involving all 12 independents and the result of the credit rating effect shows an insignificant negative relationship between the A credit rating and Sukuk yield. A significant positive relationship is found between the B credit rating and Sukuk yield. Saad and Mohamad (2012) and Saad et al. (2014) both indicated that credit rating significantly affects Sukuk yield. According to Ariff et al. (2013), Sukuk yields are significantly higher than conventional bond yields even if they have the same credit rating quality. However, Godlewski et al. (2014) included more variables in their model to control the credit worthiness of the issuer. They found that the credit rating of the issuer has a significant positive 
impact on the stock market reaction in some specifications. On the other hand, Said and Grassa (2013) pointed out that credit rating has had no effect on the development of the Sukuk market. Rahmana et al. (2013) found that the credit rating of the issuers has an insignificant relationship with the uncertainty and volatility of Sukuk spreads for all ratings apart from BB3, indicating that lowergrade bonds are subject to more changes in the asset factor.

The last independent variable is the nature of Sukuk (sovereign or corporate). Ariff and Safari (2013) investigated the differences between the yields of Sukuk and conventional bonds for different types of issuers such as, sovereigns, quasi- sovereigns, financial institutions and corporations. They suggest that issuer type may have some impact on Sukuk yields. The first sovereign issue was in 2002 by the Malaysian Global Sukuk; since then the sovereign Sukuk market has witnessed institutional and geographical diversity, in whic Bahrain, Pakistan, Malaysia and Qatar are the main national issuers (Jobst et al., 2008). As indicated in chapters 2 and 3, sovereign Sukuk are more common than corporate, while conventional bonds are more often corporate rather than sovereign. Corporate bond markets have become more important for the economy, reaching $\$ 49$ trillion in 2013. Adesina-Uthman (2011) analysed three different credit classes of corporate Sukuk (two are high investment grades and one is low) and government Sukuk in Malaysia and found that the high-grade corporate Sukuk performed better than the government Sukuk, while the low-grade Sukuk had a higher yield relative to the GII benchmark rate. The OLS test involving all 13 independent variables showed sovereign Sukuk to be significantly positively related to higher Sukuk yield. The result of the OLS rest involving all 12 independent variables after solving the multicollinearity problem shows a significantly negative relationship between sovereign Sukuk and Sukuk yield.

\section{CONCLUSION}

The results from the regression analysis suggested that maturity, size, Ijara, sovereign Sukuk, and credit rating have significant 
results on Sukuk yield. Hence, the estimation results rejected the null hypothesis that there is no relationship between the dependent variable (Sukuk yield), and the independent variables (maturity, size, risks, types of bonds, credit rating and the nature of the bonds). This indicates that these variables are important and useful for the industry players, especially the issuers and portfolio managers in articulating the strategies involving in structuring Sukuk; they are also important to the investors and traders in making capital financing or investment decisions due to their impact on Sukuk yields.

Interestingly, risk factor was found not to be significant, which is an unexpected result, as risk is considered an important factor in explaining the yield differentials in conventional bonds.

By understanding the significant factors that could affect Sukuk yields, this chapter may also assist policy makers in designing proper financial rules to encourage the development of the Sukuk market, as well as help company managers design new Sukuk issues for future financing requirements.

This study could be extended to include more economic variables and more Sukuk issues in order to validate the finding. 


\section{REFERENCES}

ABDUL RAUF, A., 2014. Determinants of risk and return performance significance on maturity based sukuk market structure. International Journal of Developing and Emerging Economics. (2)2, PP. 41-58.

AHMAD, W. and RADZI, R. M., 2011. Sustainability of Sukuk and conventional bonds during financial crisis: Malaysian capital market. Global Economy and Finance Journal. 4(2), pp. 33-45.

AL-AMINE, M. A. M., 2012. Global Sukuk and Islamic Securitization Market: Financial Engineering and product Innovation. Boston: Brill.

ANG, A. and PIAZZESI, M., 2003. A No-Arbitrage Vector Autoregression of Term Structure Dynamics with Macroeconomic and Latent Variables. Journal of Monetary Economics. (50), PP. 745-787.

ARIFF, M., SAFARI, M. and MOHAMAD, S., 2013. Sukuk securities and conventional bonds: Evidence of significant differences. Pertanika Journal of Social Science \& Humanities, 21(2), pp. 622-638.

BAGULEY, T., 2012. Serious stats: A guide to advanced statistics for the behavioral sciences. Basingstoke: Palgrave.

BATTEN, J., FETHERSTON, T. A., and HOONTRAKUL, P., 2006. Factors affecting the yields of emerging market issuers: Evidence from the Asia-Pacific region. Journal of International Financial Markets, Institutions and Money. 16, pp. 57-70.

BENGOECHEA, G., 2012. The Fallacy of Fundamentals:

Determinants of Sovereign Bond Yields in the Eurozone. [online].Available from:

59T45Thttp://www.unioviedo.es/forofinanzas/papers/F3D. The $\% 20$ Fallacy\%20of\%20undamentals \%20Determinants \%20of\%20Sover_pdf45T59T [Accessed 30 March 2016]. 
CHEIKH, A. and AMADOU, N., 2013. U.S. Interest Rates and Emerging Market Bond Yield Spreads: A Changing Relationship. The Journal of Fixed Income. 22 (4), pp. 48-52.

CHOWDHRY, S., BAYAR, Y. and KILIÇ, C., 2013. Effects of Major Macroeconomic Indicators On Emerging Markets Bond Index. [online]. Available from: http://www.iibfdergi.aku.edu.tr/pdf/15 2/2.pdf [accessed 02 April 2016].

CITIGROUP INDEX LLC., 2015. Citi fixed income indices. [online]. The Yield Book. Available from: https://www.yieldbook.com/x/ixFactSheet/factsheet month ly sukuk.pdf [Accessed 03 April 2015].

COMELLI, F., 2012. Emerging Market Sovereign Bond Spreads: Estimation and Back-testing. IMF Working Paper.12 (212), pp.1-42.

EL-KARIM, B., 2012. Factors influence Sukuk and conventional bonds in Malaysia. Global Economy and Finance Journal. (3) 14.

FATHURAHMAN, H. and FITRIATI, R., 2013. Comparative analysis of return on Sukuk and conventional bonds. American Journal of Economics. [online]. 3(3), pp. 159163. Available from:

http://article.sapub.org/pdf/10.5923.j.economics.20130303. 05.pdf

GODLEWSKI, C., ARISS, T. R. and WEILL, L., 2014. Do the type of Sukuk and choice of shari'a scholar matter?. BOFIT Discussion Papers. (21), pp. 1-4.

GUJARATI, D. N. and PORTER, D.C.,2009. Basic econometrics. 5th ed. Boston, MA: McGraw-Hill.

HARAL, T. A., 2010. Regional Head North, Senior Vice President, Arif Habib Investments Ltd. Pakistan. [online]. Available from:

59T45Thttp://mcbah.com/downloads/report/Presentations/ 
MarketingPresentation files/PALMS\%20Presentation\%20J une \%202013.pdf45T59T [Accessed 15 may 2014].

IRTURK, A., 2006. Term structure of interest rates. [online]. Available http://cseweb.ucsd.edu/ airturk/others/Term_Structure of Interest Rates.pdf [Accessed 13 June 2012].

JOBST, A., KUNZEL, P., MILLS, P. S. and SY, A., 2008. Islamic bond issuance: What sovereign debt managers need to know. International Journal of Islamic and Middle Eastern Finance and Management. 1(4), pp. 330-344.

MIN, H., 1998. Determinants of Emerging Market Bond Spread: Do Economic Fundamentals Matter. Working Paper in International Economics, Trade, and Capital Flows. 1899, pp.1-31.

NAIFAR, N. and MSEDDI, S., 2013. Sukuk spreads determinants and pricing model methodology. Afro-Asian J. Finance and Accounting. 3 (3), PP. 241-257.

NANAEVA, Z. K., 2010. How risky sukuk are: Comparative analysis of risks associated with sukuk and conventional bonds. Doctoral dissertation. British University in Dubai.

NOS'HY, A. and ROFAEL, D., 2008. The Egyptian yield curve: A key macro-economic indicator. The Egyptian Cabinet Information and Decision Support Center, Economic Issues Program.

RAHMAN, M., OMAR, M. and KASSIM, S., 2013. An application of GARCH modeling on the Malaysian sukuk spreads. Journal of Islamic Finance. [online]. Available from:

http://www.researchgate.net/publication/267507744_An_A pplication of GARCH Modeling on the Malaysian_Suk uk_Spreads [Äccessed 10 March 2014].

RUSSELL, S., 1992. Understanding the Term Structure of Interest Rates: The Expectations Theory. Federal Reserve Bank of St. Louis Review. (74)4, pp.36-50. 
SAAD, N. and MOHAMAD, N., 2012. Sukuk in Malaysian capital market. 3rd international conference on business and economic research (3rd ICBER 2012) proceeding. Indonesia, 12-13 March 2012.

SAAD, N., BIN MAMAT, M. and MOHAMAD, N., 2014. Do Sukuk issuances' characteristics have a relation to yields and weighted average cost of capital in Malaysian capital market. Australian Journal of Basic and Applied Sciences, 8(12), pp. 47-55.

SAID, A. and GRASSA, R., 2013. The Determinants of Sukuk Market Development: Does Macroeconomic Factors Influence the Construction of Certain Structure of Sukuk. Journal of Applied Finance \& Banking. 3 (5), PP. 251-267.

SIKLOS, P., 2011. Emerging Market Yield Spreads: Domestic, External Determinants and Volatility Spillovers. Global Finance Journal. 22 (2), pp. 


\section{الملخص}

تعد الصكوك الإسلامية من الأدوات الهامة للتمويل في النظام المالي الإسلامي. منذ

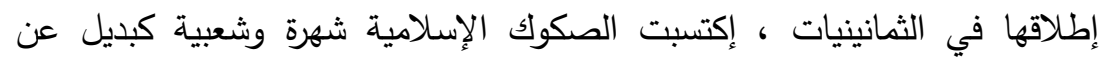

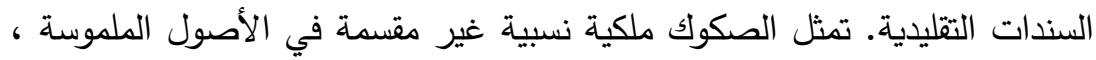

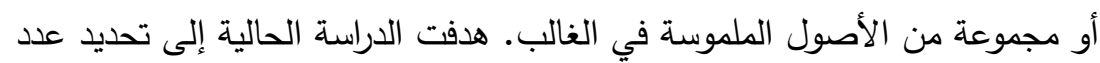

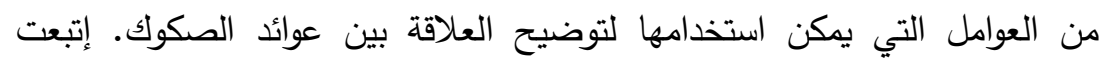
الدراسة المنهج التحليلي عن طريق استخدام تحليل الإنحدار الخطي. توصلت

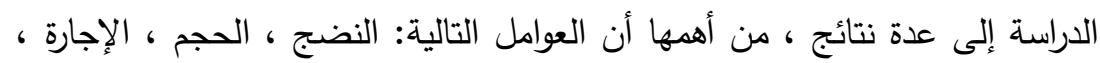
الصكوك السيادية ، والتصنيف الايتماني لها ثأثيرات هامة على على عوائد الصكوك. نتائج هذة الدراسة من الممكن أن تكون مفيدة للمستثرين للحصول على الحئي عوائد

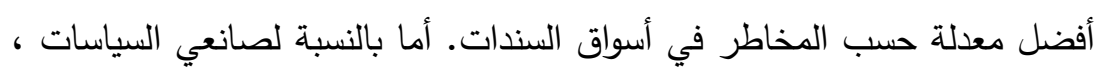

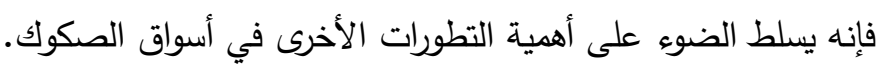
الكلمات المفتاحية: المالية الإسلامية ، السندات الإسلادية ، الصكوك. 
